\title{
The Relationship between the Teacher Candidates' Level of Media Literacy and Participation Levels to Protest and Social Change
}

\author{
Tugay Tutkun $^{1} \&$ Remzi Y. Kıncal ${ }^{1}$ \\ ${ }^{1}$ Faculty of Education, Çanakkale Onsekiz Mart University, Çanakkale, Turkey \\ Correspondence: Tugay Tutkun, Faculty of Education, Çanakkale Onsekiz Mart University, Çanakkale, Turkey.
}

Received: November 15, 2018

Accepted: December 30, 2018

Online Published: March 25, 2019

doi:10.5539/ies.v12n4p208

URL: https://doi.org/10.5539/ies.v12n4p208

\begin{abstract}
The term active citizenship is defined as participation in civil society, community and/or political life, characterized by mutual respect and non-violence and in accordance with human rights and democracy within the European context (Hoskins \& Mascherini, 2009). Promoting active citizenship is one of the European Commission's strategies for increasing social cohesion and reducing the democratic deficit across European countries within the context of the wider Lisbon process. Developing citizen awareness, knowledge and skill level of democratic rights, sensitiveness to social issues and defense against negative impact of media messages are among these objectives. European Commission considers media literacy an extremely important factor for active citizenship in today's information society. Within the European context active citizenship is defined as the combination of four dimensions; (1) protest and social change, (2) community life, (3) representative democracy and (4) democratic values (Hoskins \& Mascherini, 2009). Teachers' perceptions of citizenship are among the frequently researched subjects in terms of both their effect on students' perception of citizenship and as a citizen. The aim of this study is to explore the relationship between teacher candidates' level of media literacy and active citizenship, in terms of their participation level to protest and social change. Survey method is used to collect data in this casual comparative research. Sample of the study is 1101 freshman and senior teacher candidates studying in Faculty of Education at Çanakkale Onsekiz Mart University in the academic year of 2011-2012. The relationship between media literacy level and participation level to protest and social change is explored after controlling for the effect of socio-economic factors. It is explored that there is a significant relationship between media literacy level and participation level to protest and social change which is preserved after controlling for socio-economic factors. According to results, this study discusses how to handle digital and media literacy education in formal and informal settings in teacher education programs in relation to active citizenship.
\end{abstract}

Keywords: media literacy, active citizenship, teacher training

\section{Introduction}

Since the concept of "nation state" emerged in early 1990's, research about the citizenship mostly focused on the rights and responsibilities of individuals to the state. Within this context, Marshall (1950), emphasized the importance of civil rights, political rights and social rights. Civil rights are; equal legal rights offering justice and freedom, political rights are; the right to influence decision-making through voting, social rights are; accessing opportunities such as health and education. These rights have been defined as crucial in terms of individual rights and legal equalities in liberal states. However political rights were the weakest part of this approach since the influence of individuals on the government process depends only on voting.

\subsection{Concept of Active Citizenship}

Kerr (1999) stated that global change has thrown up following issues for states and countries, which demand a response:

- the rapid movement of people within and across national boundaries,

- a growing recognition of the rights of indigenous peoples and minorities,

- the collapse of political structures and the birth of new ones,

- the changing role of women in society,

- the impact of the global economy and changing patterns of work, 
- the effect of a revolution in information and communications technologies,

- an increasing global population, and

- the creation of new forms of community.

Mostly because of these challenges defined by Kerr (1999), beginning from the millennium there is a shift in the understanding of citizenship in terms of individual involvement in participatory democracy. Citizens' involvement in decision making process and deliberative democracy are more focused subjects in contemporary citizenship studies (Barber, 2003; Mutz, 2006). The term active citizenship emphasizes this shift taking into consideration of individual action and involvement of citizens into decision making process. It was first used in a European level context regarding to developing a competitive knowledge society and greater social cohesion (Hoskins \& Mascherini, 2009). Within this context active citizenship was described as way of empowering citizens to have their voice heard within their communities, a sense of belonging and a stake in the society in which they live, the value of democracy, equality and understanding different cultures and different opinions (European Commission DG Education and Culture, 2007).

Promoting active citizenship is one of the European Commission's strategies for increasing social cohesion and reducing the democratic deficit across European countries within the context of the wider Lisbon process. The term active citizenship is defined as "participation in civil society, community and/or political life, characterized by mutual respect and non-violence and in accordance with human rights and democracy" (Hoskins \& Mascherini, 2009).

Within the European context active citizenship is defined the combination of four dimensions; (1) protest and social change, (2) community life, (3) representative democracy and (4) democratic values. Protest and social change dimension which sometimes referred to as unconventional forms of participation includes action orientated participation such as protests, demonstrations, boycotts and political strikes that are necessary voice of influence within modern society (Ogris \& Westpal, 2006). Community life dimension includes activities that support a community such as participation in cultural or religious organizations and etc. Representative democracy dimension, mostly referring to conventional aspects of citizenship, includes activities such as voting, political party-related activities, contacting elected representatives and governmental officials (Hoskins \& Mascherini, 2009; Ogris \& Westpal, 2006). Democratic values dimension is associated with participatory democracy, civic republicanism or communitarian notion of good citizenship focus on valuing participation itself and civic virtues such as solidarity and being socially active for the good of the society (Denters, Gabriel, \& Torcal, 2007).

\subsection{Concept of Media Literacy}

The term media literacy has been in common use for almost more than 25 years. It has been associated with critical analysis of news, advertising and etc. in mass media environment (Hobbs, 2010). Although there is still disagreement about how it is to be defined, media literacy could be basically defined as being able to decode, evaluate, analyze, assess and produce both print and electronic media (Aufderheide, 1993). Similarly, Livingstone (2004) defines media literacy as the ability to access, analyze, evaluate and create messages across a variety of contexts. Hobbs (2010) states five competencies of media literacy as; (1) access, (2) analyze \& evaluate, (3) create, (4) reflect and (5) act that are working in a spiral of empowerment (see Figure 1).

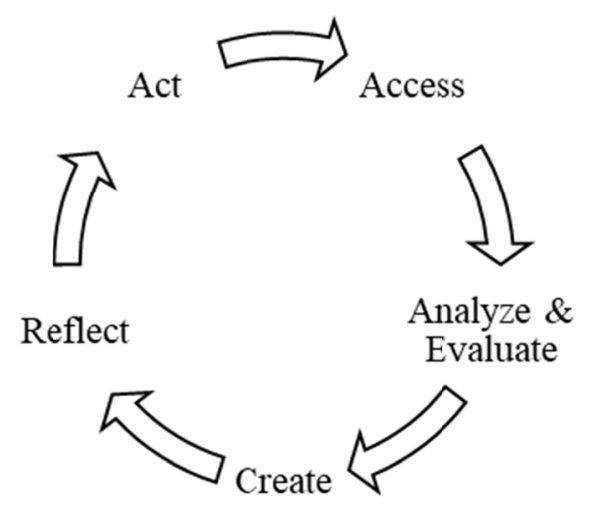

Figure 1. Essential competencies of Digital and Media Literacy (Hobbs, 2010) 
Stating the importance of media literacy, Hobbs (2010) also argues that full participation in contemporary culture requires not just consuming messages, but also creating and sharing them. Livingstone (2004) argues that media literacy should be recognized as a key means, even a right, by which citizens participate in society and by which the state regulates the manner and purposes of citizens' participation. Hobbs (2010) define digital and media literacy as a constellation of life skills that are necessary for full participation in today's media-saturated, information-rich society. These include the ability to do the following (Hobbs, 2010):

- Make responsible choices and access information by locating and sharing materials and comprehending information and ideas,

- Analyze messages in a variety of forms by identifying the author, purpose and point of view, and evaluating the quality and credibility of the content,

- Create content in a variety of forms, making use of language, images, sound, and new digital tools and technologies,

- Reflect on one's own conduct and communication behavior by applying social responsibility and ethical principles,

- Take social action by working individually and collaboratively to share knowledge and solve problems in the family, workplace and community, and by participating as a member of a community.

Democracy, participation and active citizenship are also one of the major objectives of media literacy education (European Commission DG Education and Culture, 2007). Developing citizens' awareness, knowledge and skill level of democratic rights, sensitiveness to social issues and defense against negative impact of media messages are among these objectives.

People must acquire multimedia communication skills that include the ability to compose messages using language, graphic design, images, and sound, and know how to use these skills to engage in the civic life of their communities (Hobbs, 2010). Jenkins, Purushhotma, Weigel, Clinton, and Robison (2006) identifies twelve new media literacies (NMLs) that are necessary for a full participation in today's media environment: (1) play, (2) performance, (3) simulation, (4) appropriation, (5) multitasking, (6) distributed cognition, (7) collective intelligence, (8) judgment, (9) transmedia navigation, (10) networking, (11) negotiation, and (12) visualization.

\subsection{Purpose of the Study}

As seen in this brief exploration of the terms, active citizenship and media literacy, are interrelated concepts and necessary skills and competencies in today's global and multicultural world. Having digital and media literacy competencies, people recognize personal, corporate and political agendas and are empowered to speak out on behalf of the missing voices and omitted perspectives in the community. By doing so, people use their powerful voices and their rights improve the world and democratic culture.

Teachers' perceptions and behaviors related to citizenship are among the frequently researched subjects in terms of both their effect on students' perception of citizenship and as a citizen. In this context, aim of this study is to explore the relationship between teacher candidates' level of media literacy and active citizenship, in terms of their participation level to protest and social change.

\subsection{Research Questions}

The relationship between the media literacy level and the participation level to protest and social change is explored after controlling for the effect of socio-economic factors. In this regard, an attempt was made to answer the following questions.

- What is the candidate teachers level on media literacy and protest and social change?

- Does candidate teachers' media literacy level significantly differ by gender?

- Does candidate teachers' media literacy level significantly differ by grade level?

- Does candidate teachers' media literacy level significantly differ by department?

- Do candidate teachers' participation level to protest and social change significantly differ by gender?

- Do candidate teachers' participation level to protest and social change significantly differ by grade level?

- Do candidate teachers' participation level to protest and social change significantly differ by department?

- Does candidate teachers' media literacy level have significant correlation with their participation level to protest and social change? 
- If so, how the correlation between candidate teachers' media literacy level and participation level to protest and social change differs after controlling for the effects of; gender, grade level, department, mother's education level, father's education level, monthly family income, number of siblings.

\section{Method}

Survey method is used to collect data in this casual comparative and correlational research. The study group, data collection tools, and analysis of data headings are presented in this section.

\subsection{Study Group}

The study group consists of 1101 freshman and senior teacher candidates studying in Faculty of Education at Çanakkale Onsekiz Mart University, Turkey in the academic year of 2011-2012. Descriptive statistics related to the research group is given in Table 1.

Table 1. Descriptive statistics of participants

\begin{tabular}{|c|c|c|c|c|c|c|}
\hline \multirow{2}{*}{ Department } & \multirow{2}{*}{ Gender } & \multicolumn{2}{|c|}{ Grade } & \multirow{2}{*}{ Total } & \multicolumn{2}{|c|}{ Total } \\
\hline & & $1 \mathrm{st}$ & 4th & & f & $\%$ \\
\hline \multirow{2}{*}{ German Language Education } & f & 35 & 22 & 57 & \multirow{2}{*}{62} & \multirow{2}{*}{$5.6 \%$} \\
\hline & $\mathrm{m}$ & 2 & 3 & 5 & & \\
\hline \multirow{2}{*}{ Computer \& Instructional Technology Education } & f & 33 & 19 & 52 & \multirow{2}{*}{116} & \multirow{2}{*}{$10.5 \%$} \\
\hline & $\mathrm{m}$ & 27 & 37 & 64 & & \\
\hline \multirow{2}{*}{ Geography Education } & f & 4 & 10 & 14 & \multirow{2}{*}{53} & \multirow{2}{*}{$4.5 \%$} \\
\hline & $\mathrm{m}$ & 23 & 16 & 39 & & \\
\hline \multirow{2}{*}{ Science Education } & f & 57 & 45 & 102 & \multirow{2}{*}{135} & \multirow{2}{*}{$12.3 \%$} \\
\hline & $\mathrm{m}$ & 10 & 23 & 33 & & \\
\hline \multirow{2}{*}{ English Language Education } & f & 32 & 50 & 82 & \multirow{2}{*}{109} & \multirow{2}{*}{$9.9 \%$} \\
\hline & $\mathrm{m}$ & 20 & 7 & 27 & & \\
\hline \multirow{2}{*}{ Japanese Language Education } & f & 14 & 15 & 29 & \multirow{2}{*}{43} & \multirow{2}{*}{$3.9 \%$} \\
\hline & $\mathrm{m}$ & 8 & 6 & 14 & & \\
\hline \multirow{2}{*}{ Music Education } & f & 17 & 17 & 34 & \multirow{2}{*}{51} & \multirow{2}{*}{$4.6 \%$} \\
\hline & $\mathrm{m}$ & 9 & 8 & 17 & & \\
\hline \multirow{2}{*}{ Early Childhood Education } & f & 69 & 68 & 137 & \multirow{2}{*}{152} & \multirow{2}{*}{$13.8 \%$} \\
\hline & $\mathrm{m}$ & 13 & 2 & 15 & & \\
\hline \multirow{2}{*}{ Art Education } & $f$ & 24 & 19 & 43 & \multirow{2}{*}{50} & \multirow{2}{*}{$4.5 \%$} \\
\hline & $\mathrm{m}$ & 3 & 4 & 7 & & \\
\hline Primary School Fducation & f & 58 & 56 & 114 & 163 & $148 \%$ \\
\hline 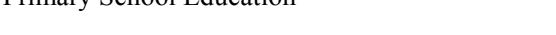 & $\mathrm{m}$ & 16 & 33 & 49 & & 17.070 \\
\hline History Education & $f$ & 5 & 15 & 20 & 40 & $45 \%$ \\
\hline Hitsiory Laucaliorit & $\mathrm{m}$ & 19 & 10 & 29 & T) & 4.070 \\
\hline & $\mathrm{f}$ & 37 & 30 & 67 & & \\
\hline Turkish Language Education & $\mathrm{m}$ & 20 & 31 & 51 & 118 & $10.7 \%$ \\
\hline Total & & 555 & 546 & 1101 & 1101 & $100 \%$ \\
\hline
\end{tabular}

Table 1 above, illustrates the general characteristics of the participants. $1^{\text {st }}$ and $4^{\text {th }}$ graders embody almost the same percent of the participants. The Primary School Education is the largest sub group with $14.8 \%$, where Japanese Language Education is the smallest sub group with $3.9 \%$ of the participants in the sample.

\subsection{Data Collection Tools}

The data collection tool was structured around 3 main sections: demographics, protest and social change and media literacy. The demographics section contained 7 items, asking participants about their gender, grade, department, mother's education level, father's education level, monthly income of the family and number of siblings in the family.

The data about the candidate teachers' level of participation to protest and social change activities were collected by the scale which originally developed by Hoskins, Villalba, \& Saisana (2012) and adopted to Turkish language by Tutkun (2013). There are four sub dimensions in this scale; (1) protest, (2) engagement in trade union organizations, (3) engagement in environmental organizations, (4) engagement in human rights organizations. All 
these dimensions measured on a 5-point Likert-type scale except membership to organizations which is measured as 'member' or 'not member'. Protest dimension measured with 8 different type of protest activities. Other three dimensions measured by three items for each referring to 'donating money', 'volunteering in activities' and 'participation in activities'.

The data about the candidate teachers' level of media literacy were collected through New Media Literacies Scale (NML) which originally developed by Literat (2011) and adopted to Turkish language by Tutkun (2013). The NML scale intends to measure level of twelve media literacy skills identified by Jenkins (2006); (1) play, (2) performance, (3) simulation, (4) appropriation, (5) multitasking, (6) distributed cognition, (7) collective intelligence, (8) judgment, (9) transmedia navigation, (10) networking, (11) negotiation, and (12) visualization. All these skills measured on a 5-point Likert-type scale ( $1=$ Strongly Disagree, $5=$ Strongly Agree).

\subsection{Data Analysis}

The data were analyzed by SPSS Statistics software. In the analysis process t-test was conducted to determine whether the mean scores of "media literacy level" and "participation level to protest and social change" differ by gender and grade level. ANOVA was conducted to determine whether the candidate teachers" "media literacy level" and "participation level to protest and social change" differ by department. Pearson Correlation coefficient is calculated to determine the relationship between the "media literacy level" and "participation level to protest and social change" ANCOVA also conducted explore if the correlation between the "media literacy level" and "participation level to protest and social change" preserved after controlling for factors, namely; gender, grade level, department.

\section{Results}

Table 2. Descriptive statistics for media literacy and participation level to protest and social change

\begin{tabular}{lccccc}
\hline & N & Min. & Max. & Mean & S.D. \\
\hline Media Literacy Level & 1101 & 1.88 & 4.59 & 3.4285 & .44687 \\
Participation Level to Protest and Social Change & 1101 & 1.00 & 5.00 & 2.4603 & .97628 \\
\hline
\end{tabular}

Table 2 illustrates basic descriptive statistics for both media literacy level and participation level to protest and social change. For media literacy, mean score of 1101 candidate teachers is 3.43 with a standard deviation of 0.45 . Basically this mean score could be considered as intermediate since the scale is between 1 and 5 . On the participation level to protest and social change mean score of 1101 candidate teachers is 2.46 with a standard deviation of 0.98 . This mean score could also be considered as low since the scale is between 1 and 5 . Candidate teacher's level of participation to protest and social change activities is less than the mid-point of the scale.

Table 3. Results of t-test for media literacy level by gender

\begin{tabular}{|c|c|c|c|c|c|c|c|}
\hline & Gender & $\mathrm{f}$ & Mean & S.D. & $\mathrm{t}$ & df & $\mathrm{p}$ \\
\hline \multirow{2}{*}{ Media Literacy Level } & $\mathrm{f}$ & 751 & 3.393 & .441 & \multirow{2}{*}{-3.873} & \multirow{2}{*}{1099} & \multirow{2}{*}{$.000^{*}$} \\
\hline & $\mathrm{m}$ & 350 & 3.504 & .450 & & & \\
\hline
\end{tabular}

$*: \mathrm{p}<.05$.

Table 3 illustrates the results of independent-samples t-test conducted to compare the media literacy level in female and male teacher candidates. There is a significant difference between female $(\mathrm{M}=3.39, \mathrm{SD}=0.44)$ and male $(\mathrm{M}=3.5, \mathrm{SD}=0.45)$ teacher candidates; $\mathrm{t}(1099)=-3.873, \mathrm{p}=0.000$.

Table 4. Results of t-test for media literacy level by grade level

\begin{tabular}{lccccccc}
\hline & Grade & $\mathrm{f}$ & Mean & S.D. & $\mathrm{t}$ & $\mathrm{df}$ & $\mathrm{p}$ \\
\hline \multirow{2}{*}{ Media Literacy Level } & $1^{\text {st }}$ Grader & 555 & 3.436 & .449 & \multirow{2}{*}{.599} & \multirow{2}{*}{1099} & \multirow{2}{*}{.549} \\
& $4^{\text {th }}$ Grader & 546 & 3.420 & .445 & &
\end{tabular}

$*: \mathrm{p}<.05$.

Table 4 illustrates the results of independent-samples t-test conducted to compare the media literacy level in 
freshman and senior teacher candidates. There is no significant difference between $1^{\text {st }}$ graders $(\mathrm{M}=3.44, \mathrm{SD}=0.45)$ and $4^{\text {th }}$ graders $(\mathrm{M}=3.42, \mathrm{SD}=0.45) ; \mathrm{t}(1099)=0.599, \mathrm{p}=0.549$.

Table 5. Results of ANOVA for media literacy level by department

\begin{tabular}{|c|c|c|c|c|c|}
\hline & Sum of Squares & $\mathrm{df}$ & Mean Square & $\mathrm{F}$ & Sig. \\
\hline Between Groups & 5.287 & 11 & .481 & & \\
\hline Within Groups & 214.372 & 1089 & .197 & 2.442 & $.005^{*}$ \\
\hline Total & 219.660 & 1100 & & & \\
\hline
\end{tabular}

$*: \mathrm{p}<.05$.

Table 5 illustrates the results of one-way between subjects ANOVA conducted to compare the effect of department in media literacy level of candidate teachers. There is a significant effect of department on media literacy level at the $\mathrm{p}<.05$ level for the media literacy level $(\mathrm{F}(11,1089)=2.442, \mathrm{p}=0.005)$. Post hoc comparisons using the Tukey HSD test indicated that the mean score of teacher candidates studying Early Childhood Education $(\mathrm{M}=3.32$, $\mathrm{SD}=0.44$ ) was significantly different than the teacher candidates studying Computer \& Instructional Technology Education $(\mathrm{M}=3.53, \mathrm{SD}=0.47)$, Science Education $(\mathrm{M}=3.50, \mathrm{SD}=0.43)$ and English Language Education $(\mathrm{M}=3.50, \mathrm{SD}=0.41)$.

Table 6. Results of t-test for participation level to protest and social change by gender

\begin{tabular}{|c|c|c|c|c|c|c|c|}
\hline & Gender & $\mathrm{f}$ & Mean & S.D. & $\mathrm{t}$ & $\mathrm{df}$ & $\mathrm{p}$ \\
\hline \multirow{2}{*}{ Participation Level to Protest and Social Change } & $\mathrm{f}$ & 751 & 2.426 & .978 & \multirow{2}{*}{-1.706} & \multirow{2}{*}{1099} & \multirow{2}{*}{.088} \\
\hline & $\mathrm{m}$ & 350 & 2.534 & .971 & & & \\
\hline
\end{tabular}

$*: \mathrm{p}<.05$.

Table 6 illustrates the results of independent-samples t-test conducted to compare the participation level to protest and social change in female and male teacher candidates. There is no significant difference between females $(\mathrm{M}=2.43, \mathrm{SD}=0.98)$ and males $(\mathrm{M}=2.53, \mathrm{SD}=0.97) ; \mathrm{t}(1099)=-1.706, \mathrm{p}=0.88$.

Table 7. Results of t-test participation level to protest and social change by grade level

\begin{tabular}{|c|c|c|c|c|c|c|c|}
\hline & Grade & $\mathrm{f}$ & Mean & S.D. & $\mathrm{t}$ & $\mathrm{df}$ & $\mathrm{p}$ \\
\hline \multirow{2}{*}{ Participation Level to Protest and Social Change } & $1^{\mathrm{st}}$ & 555 & 2.427 & .989 & \multirow{2}{*}{-1.145} & \multirow{2}{*}{1099} & \multirow{2}{*}{.252} \\
\hline & $4^{\text {th }}$ & 546 & 2.494 & .963 & & & \\
\hline
\end{tabular}

*: $\mathrm{p}<.05$.

Table 7 illustrates the results of independent-samples t-test conducted to compare participation level to protest and social change in $1^{\text {st }}$ and $4^{\text {th }}$ grader teacher candidates. There is no significant difference between $1^{\text {st }}$ graders $(\mathrm{M}=2.43, \mathrm{SD}=0.99)$ and $4^{\text {th }}$ graders $(\mathrm{M}=2.45, \mathrm{SD}=0.96) ; \mathrm{t}(1099)=-1.145, \mathrm{p}=0.252$.

Table 8. Results of ANOVA for participation level to protest and social change

\begin{tabular}{|c|c|c|c|c|c|}
\hline & Sum of Squares & $\mathrm{df}$ & Mean Square & $\mathrm{F}$ & Sig. \\
\hline Between Groups & 6.221 & 11 & .566 & & \\
\hline Within Groups & 1042.208 & 1089 & .957 & .591 & .837 \\
\hline Total & 1048.429 & 1100 & & & \\
\hline
\end{tabular}

$*: \mathrm{p}<.05$.

Table 8 illustrates the results of one-way between subjects ANOVA conducted to compare the effect of department in participation level to protest and social change. There is no significant effect of department on the participation level to protest and social change $(\mathrm{F}(11,1089)=0.591, \mathrm{p}=0.837)$. 
Table 9. Results of correlation among media literacy level and participation level to protest and social change

\begin{tabular}{lcc}
\hline & Participation Level to Protest and Social Change & $p$ \\
\hline Media Literacy Level & .173 & $.000^{* * *}$ \\
\hline$* *$ C Correlation is significant at the 0.01 level (2-tailed). & &
\end{tabular}

Table 9 illustrates the results of Pearson product-moment correlation coefficient computed to assess the relationship between the media literacy level and the participation level to protest and social change. There is a significant positive correlation between these two variables; $\mathrm{r}=0.173, \mathrm{n}=1101, \mathrm{p}=0.000$.

Table 10. Results of ANCOVA for participation level to protest and social change by media literacy level

\begin{tabular}{lcccccc}
\hline Source & Type III Sum of Squares & $\mathrm{df}$ & Mean Square & $\mathrm{F}$ & Sig. & Partial Eta Squared \\
\hline Corrected Model & $45.666^{\mathrm{a}}$ & 5 & 9.133 & 9.973 & .000 & .044 \\
Intercept & 391.005 & 1 & 391.005 & 426.971 & .000 & .281 \\
Gender & .415 & 1 & .415 & .453 & .501 & .000 \\
Grade Level & 1.002 & 1 & 1.002 & 1.095 & .296 & .001 \\
Department & .022 & 1 & .022 & .024 & .877 & .000 \\
Media Literacy Level (1-5) & 41.300 & 2 & 20.650 & 22.550 & .000 & .040 \\
Error & 1002.763 & 1095 & .916 & & & \\
Total & 7712.948 & 1101 & & & & \\
Corrected Total & 1048.429 & 1100 & & & & \\
\hline
\end{tabular}

a. R Squared $=.044$ (Adjusted R Squared $=.039)$

Table 10 illustrates the results of ANCOVA conducted to compare the effectiveness of 5 media literacy levels controlling for gender, grade level and department. The independent variable, media literacy level, included three levels: (1) low, (2) moderate and (3) high. The dependent variable was the participation level to protest and social change and covariates were the teacher candidates' demographics, namely; gender, grade level and department. Levene's test and normality checks were carried out and the assumptions met. There was a significant difference in mean participation level to protest and social change $[\mathrm{F}(2.1095), \mathrm{p}=0.000]$ between the media literacy levels whilst adjusting for gender, grade level and department. Post hoc tests showed there was a significant difference between low and moderate media literacy levels $(\mathrm{p}=0.004)$, low and high media literacy levels $(\mathrm{p}=0.000)$ and moderate and high media literacy levels $(\mathrm{p}=0.000)$. Comparing the estimated marginal means showed that the highest participation level to protest and social change was observed on high media literacy level $(\mathrm{M}=2.88)$ compared to low $(\mathrm{M}=2.17)$ and moderate $(\mathrm{M}=2.43)$ media literacy levels. However, only 4\% (Partial Eta Squared $=0.04)$ of the total variance in participation level to protest and social change was accounted for the three levels of media literacy controlling for the effect of covariates.

\section{Discussion}

As candidate teachers take steps to teach their students both formally and informally to be world citizens in the 21 st Century, teacher education curriculums need to be reviewed in terms of ensuring providing necessary skills. One of these skills is media literacy which would enable them to have the opportunity to become involved, feel like they belong to a local and global community and use their powerful voices and their rights.

There are variety of factors expected to be affecting participation level to protest and social change in terms of active citizenship such as; gender, department, grade level, annual income and etc. Media literacy level is one of these factors related to and expected to affect protest and social change behaviors. Media literacy level of individuals affects their ability to both involvement and participation to society and uses their powerful voices and their rights (Hoskins, 2006; Hoskins \& Mascherini, 2009; Jenkins, Clinton, Purushatma, Robison, \& Weigel, 2007; Hobbs, 2010; European Commission, 2012; Livingstone, 2004). Matching the literature, a significant positive correlation was found between candidate teachers' media literacy level and participation level to protest and social change. There was also a significant effect of media literacy levels on participation level to protest and social change after controlling for the effects of gender, department and grade level.

Considering the inherent shortcomings of survey method, this this study also points out the need to combine quantitative qualitative research in order to achieve a better understanding of the concept media literacy, protest and social change behaviors and their interrelations. 
The results of this study in general support the notion that media literacy skills of candidate teachers should be improved by formal or informal education which affects their participation to democratic society as active citizens. So that, they could be able to demonstrate and transfer these skills to their students when they become both active citizens and active teachers.

\section{Acknowledgments}

This paper was part of the first author's doctoral dissertation, in which the second author served as the advisor.

\section{References}

Aufderheide, P. (1993). Media Literacy: A Report of the National Leadership Conference on Media Literacy. Queenstown, Maryland: The Aspen Institute Wye Center.

Barber, B. R. (2003). Strong Democracy: Participatory Politics for a New Age. Los Angeles: University of Southern California.

Buckingham, D. (2009). Media Education. Cambridge: Polity Press.

Denters, B., Gabriel, O., \& Torcal, M. (2007). Political Confidence in Representative Democracies. Socio-Cultural vs. Political Explanations. In J. Deth, R. Montero, \& A. Westholm (Eds.), Citizenship and Involvement in European Democracies: A Comparative Analysis (pp. 66-87). London: Routledge.

European Commission DG Education and Culture. (2007). Study on Active Citizenship Education. European Comission.

European Commission. (2012). Media Programme-Overview. Retrieved from http://ec.europa.eu/culture/media/media-literacy/index_en.htm

Hobbs, R. (2010). Digital and Media Literacy: A Plan of Action. Washington: The Aspen Institute.

Hoskins, B. (2006). Draft framework on Indicators for Active Citizenship. Ispra: CRELL.

Hoskins, B. L., \& Mascherini, M. (2009). Measuring Active Citizenship through the Development of a $\begin{array}{lllll}\text { Composite Indicator. Social Indicators } & \text { Research, } & \text { 19(3). }\end{array}$ https://doi.org/10.1007/s11205-008-9271-2

Hoskins, B., Villaiba, C. M., \& Saisana, M. (2012). The 2011 Civic Competence Indicator (CCCI-2). Luxembourg: Publications Office of the European Union.

Jenkins, H., Clinton, K., Purushatma, R., Robison, R., \& Weigel, M. (2007). Confronting the Challenges of a Participatory Culture: Media Education for the 21st Century. Nordic Journal of Media Literacy, 2(2), 98-113.

Jenkins, H., Purushhotma, R., Weigel, M., Clinton, K., \& Robison, A. J. (2006). Confronting the Challenges of Participatory Culture: Media Education in 21st Century. London: The MIT Press.

Kerr, D. (1999). Citizenship Education in the Curriculum: An International Review. The School Field, 3/4(10), $5-32$.

Literat, I. (2011). Measuring New Media Literacies: Towards the Development of a Comprehensive Assessment Tool. Teachers College Educational Technology Conference (TCETC) Proceedings. New York: TCETC.

Livingstone, S. (2004). What is media literacy? Intermedia (pp. 18-20).

Marshall, T. H. (1950). Citizenship and Social Class. In T. H. Marshall (Ed.), Citizenship and Social Class and Other Essays. Cambridge: Cambridge University Press.

Mutz, D. C. (2006). Hearing the other side: Deliberative versus participatory democracy. Cambridge: Cambridge University Press. https://doi.org/10.1017/CBO9780511617201

Ogris, G., \& Westpal, S. (2006). Active Citizenship Indicators on the Political Domain. Vienna: SORA: Institute for Social Research and Analysis.

Oxstrand, B. (2009). Media Literacy Education-A discussion about Media education in the Western countries, Europe and Sweden. The Nordmedia09 Conference in Karlstad University (pp. 13-15). Sweden.

Tutkun, T. (2013). The Relationship between Teacher Candidates' Media Literacy Level and Participation Levels to Representative Democracy, Protest and Social Change Dimensions of Active Citizenship (Unpublished Dissertation, Çanakakle).

Verba, S., \& Nie, H. (1972). Participation in America: Political Democracy and Social Equality. New York: 
Harper and Row.

\section{Copyrights}

Copyright for this article is retained by the author(s), with first publication rights granted to the journal.

This is an open-access article distributed under the terms and conditions of the Creative Commons Attribution license (http://creativecommons.org/licenses/by/4.0/). 